\title{
The Geologic and Hydrogeologic Setting of the Waste Isolation Pilot Plant
}

\author{
Peter N. Swift and Thomas F. Corbet \\ Sandia National Laboratories, P.O. Box 5800, Albuquerque, NM 87185, USA
}

\section{Introduction}

The Waste Isolation Pilot Plant (WIPP) is a mined repository constructed by the United States Department of Energy for the permanent disposal of transuranic wastes generated since 1970 by activities related to national defense. The WIPP is located $42 \mathrm{~km}$ east of Carlsbad, New Mexico, in bedded salt (primarily halite) of the Late Permian (approximately 255 million years old) Salado Formation, $655 \mathrm{~m}$ below the land surface. Characterization of the site began in the mid-1970s. Construction of the underground disposal facilities began in the early 1980s, and the facility received final certification from the United States Environmental Protection Agency in May 1998. Disposal operations are planned to begin following receipt of a final permit from the State of New Mexico and resolution of legal issues (see Reference 1, this volume, for additional information about the history of the project).

Like other proposed geologic repositories for radioactive waste, the WIPP relies on a combination of engineered and natural barriers to isolate the waste from the biosphere. Engineered barriers at the WIPP, including the seals that will be emplaced in the access shafts when the facility is decommissioned, are discussed in the context of facility design elsewhere in this volume. ${ }^{2}$ Physical properties of the natural barriers that contribute to the isolation of radionuclides are discussed here in the context of the physiographic, geologic, and hydrogeologic setting of the site.

\section{Site Physiography}

The WIPP is located in semiarid, sparsely inhabited rangeland at an elevation of approximately $1040 \mathrm{~m}$ above sea level. ${ }^{3}$ Topographic relief in the region is slight, with an average east-to-west 


\section{DISCLAIMER}

This report was prepared as an account of work sponsored by an agency of the United States Government. Neither the United States Government nor any agency thereof, nor any of their employees, make any warranty, express or implied, or assumes any legal liability or responsibility for the accuracy, completeness, or usefulness of any information, apparatus, product, or process disclosed, or represents that its use would not infringe privately owned rights. Reference herein to any specific commercial product, process, or service by trade name, trademark, manufacturer, or otherwise does not necessarily constitute or imply its endorsement, recommendation, or favoring by the United States Government or any agency thereof. The views and opinions of authors expressed herein do not necessarily state or reflect those of the United States Government or any agency thereof. 


\section{DISCLAIMER}

Portions of this document may be illegible in electronic image products. Images are produced from the best available original document. 
slope at the site of $10 \mathrm{~m} / \mathrm{km}$. Surface drainage is intermittent, and the nearest perennial stream is the Pecos River, $20 \mathrm{~km}$ southwest of the site boundary. The most prominent topographic feature in the vicinity of the site is Nash Draw, a shallow, closed depression 5 to $10 \mathrm{~km}$ wide, approximately $30 \mathrm{~km}$ long, and 50 to $100 \mathrm{~m}$ deep (Figure 1). Surface facilities at the WIPP are on a nearly flat plain 5 to $8 \mathrm{~km}$ east of Nash Draw, in a region of stabilized sand dunes. Active sand dunes are present southeast of the site.

\section{Regional Geology}

\subsection{Summary of Geologic History}

The geologic history of southeastern New Mexico can be subdivided into three broad phases: a period from approximately $1.5 \times 10^{9}$ to $1.1 \times 10^{9}$ years ago, during which the metamorphic and igneous rocks that make up the continental crust of the region formed; a period from $1.1 \times 10^{9}$ to approximately $0.6 \times 10^{9}$ years ago from which no rock record is preserved; and the period from approximately 600 million years ago to the present, represented by approximately $5,500 \mathrm{~m}$ of sedimentary rocks at the WIPP site. $^{3}$ Only this last stage is relevant to isolation of radionuclides at the WIPP.

The geologic history of southeastern New Mexico and west Texas has been described in detail by numerous authors ${ }^{4,5,6,7,8}$ and is summarized only briefly here. Regional subsidence beginning approximately 500 to 450 million years ago, in the Cambrian and Ordovician Periods, resulted in deposition of marine sediments across a large portion of North America. Localized subsidence beginning in the Late Pennsylvanian Period, approximately 300 million years ago, created the Delaware Basin, which is a structural depression occupying approximately $23,000 \mathrm{~km}^{2}$, and extending from north of Carlsbad, New Mexico, southward into Texas (Figure 1). Most of the sedimentary rocks at the WIPP, including the Salado Formation that hosts the repository, were deposited in the Permian Period (286 to 245 million years ago*) during continued subsidence in the Delaware Basin and the surrounding region.

* Geologic ages are from Reference 9. 


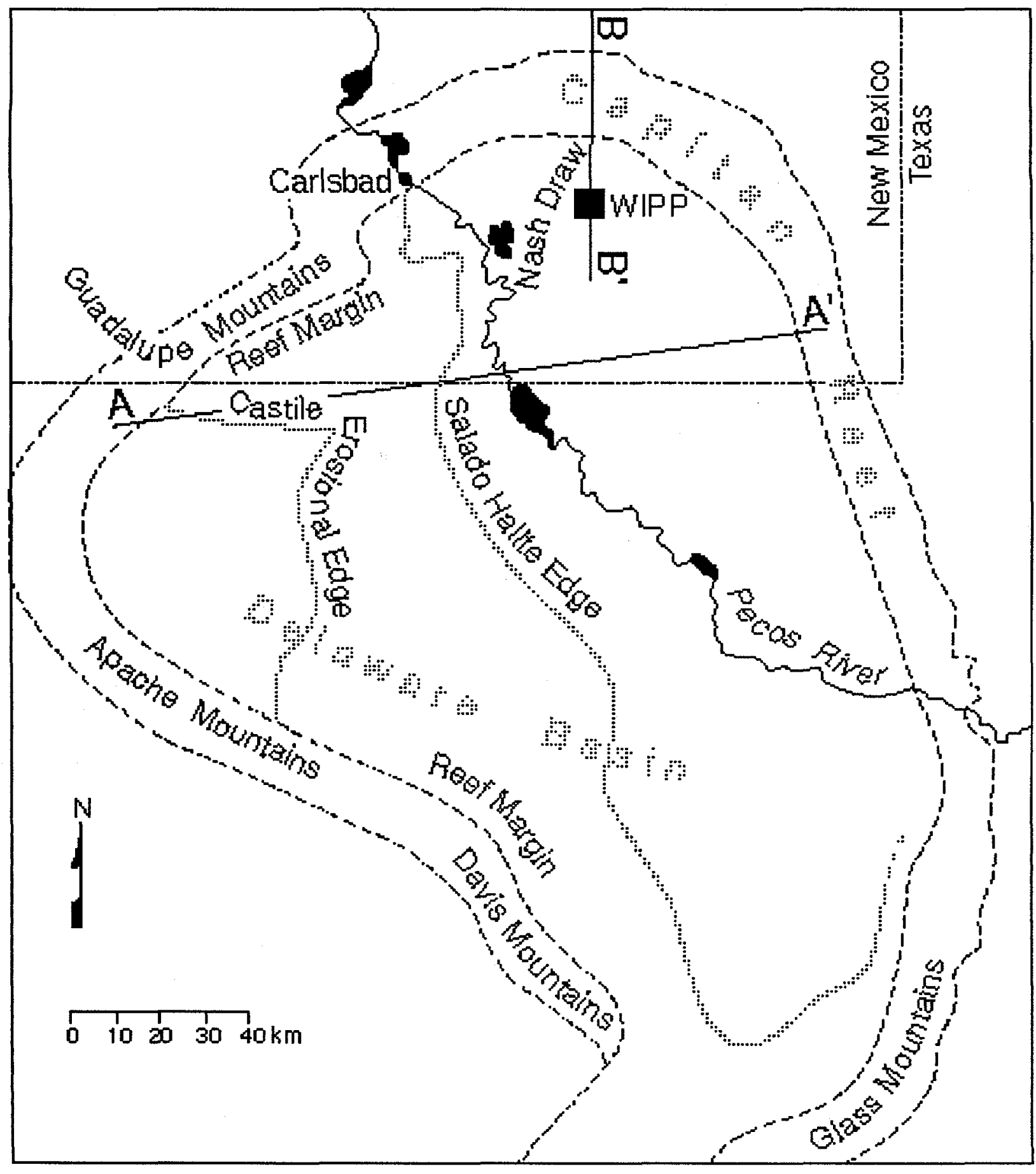

Figure 1. Location of the WIPP site in southeastern New Mexico. Lines A-A' and B-B' show the locations of cross sections shown in Figures 2 and 3 (modified from Reference 10).

Relatively rapid subsidence in the Delaware Basin during the Early Permian resulted in deposition of a sequence of deep-water sandstones, shales, and limestones rimmed by massive limestone reefs 
and shallow-water back-reef deposits. The thickest of the reef deposits, the Capitan Limestone, defines the boundaries of the Delaware Basin shown in Figure 1.

Subsidence slowed during the Late Permian, and the consequent decrease in the supply of clastic sediments and the increasing isolation of the marine basin from the open ocean resulted in deposition of a thick sequence of evaporite minerals. Anhydrites, halites, and carbonates of the Castile Formation were deposited in the interior of the basin within the Capitan reef. Regional subsidence continued as the basin filled, and halites of the Salado Formation were deposited outward from the basin center over the Capitan reef and the shallow-water deposits landward from it. Latest Permian-age evaporites, carbonates, and clastic rocks of the Rustler Formation and the Dewey Lake Red Beds record the end of regional subsidence and include the last Permian-age marine rocks in southeastern New Mexico. The overlying sandstones of the Triassic (245 to 208 million years ago) Dockum Group (Santa Rosa Formation) reflect continental deposition and mark the onset of a period of tectonic stability in the basin that lasted more than 200 million years, until late in the Tertiary Period.

Permian and Triassic strata of the Delaware Basin now dip gently (generally less than $1^{\circ}$ ) to the east, and erosion has exposed progressively older units toward the western edge of the basin (Figures 1 and 2; note extreme vertical exaggeration in Figure 2). This tilting reflects the Late Tertiary and early Quaternary uplift of the Guadalupe and Delaware Mountains along the western margin of the basin approximately 10 million to 1 million years ago, ${ }^{8}$ which exposed the Capitan reef at the land surface. North and east of the WIPP, the reef has not been uplifted and the subsurface geology has changed little since the Permian (Figure 3, note extreme vertical exaggeration.)

Thin ( 0 to $90 \mathrm{~m}$ thick) deposits of latest Tertiary and Quaternary gravels and sandstones of the Gatuña Formation overlie the older strata unconformably at several locations throughout the WIPP region, recording deposition in intermittent and perennial stream channels that were part of an ancestral Pecos River drainage system. ${ }^{11,12}$ At the WIPP site, the mid-Quaternary (approximately 500,000 years old) Mescalero caliche overlies the Gatuña and older rocks and underlies the surficial soils and sands. ${ }^{3}$ 
A

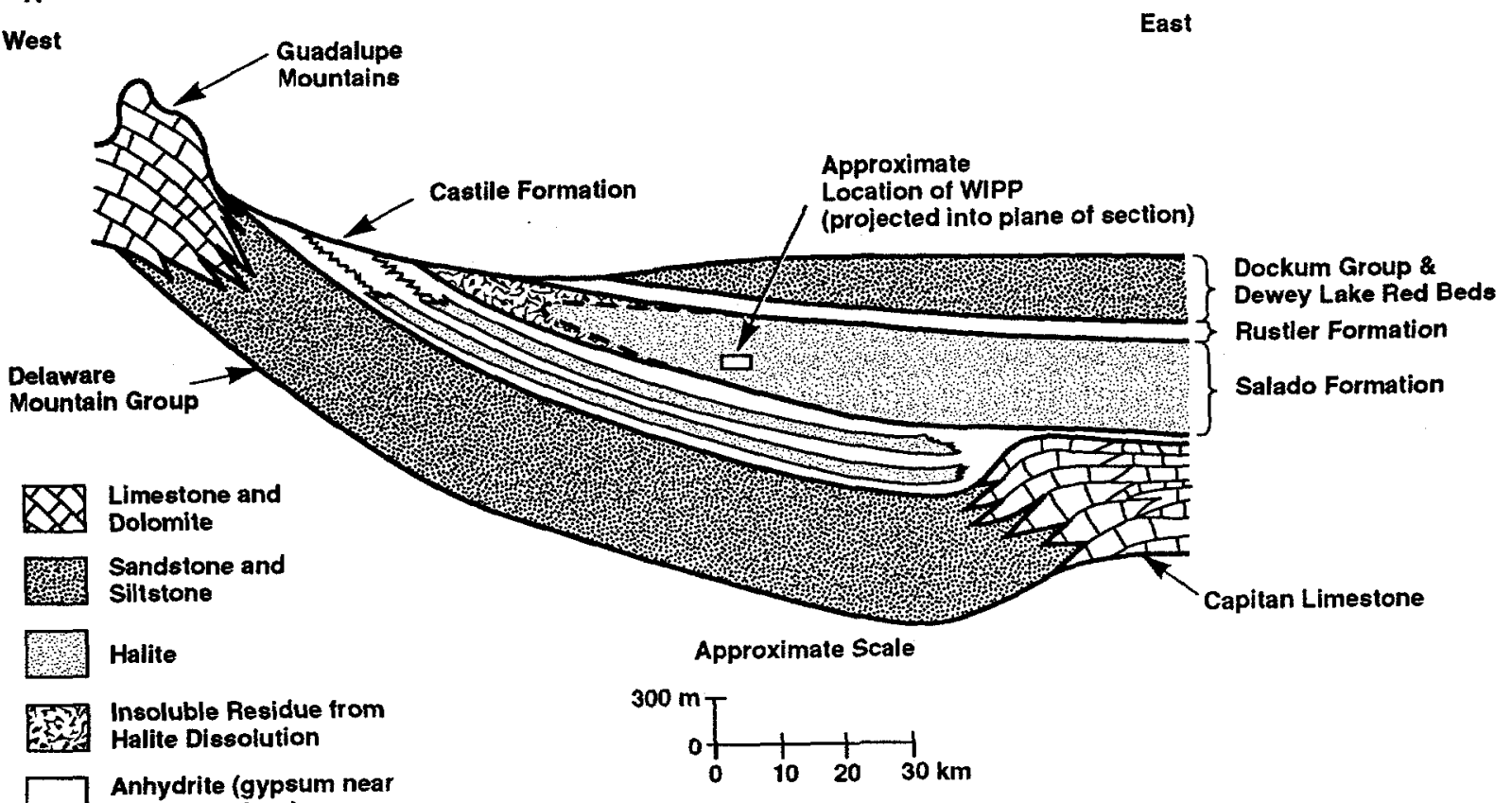
ground surface)

Figure 2. East-West geologic cross section through the Delaware Basin. Note extreme vertical exaggeration. Line of section is shown in Figure 1 (modified from Reference 13).

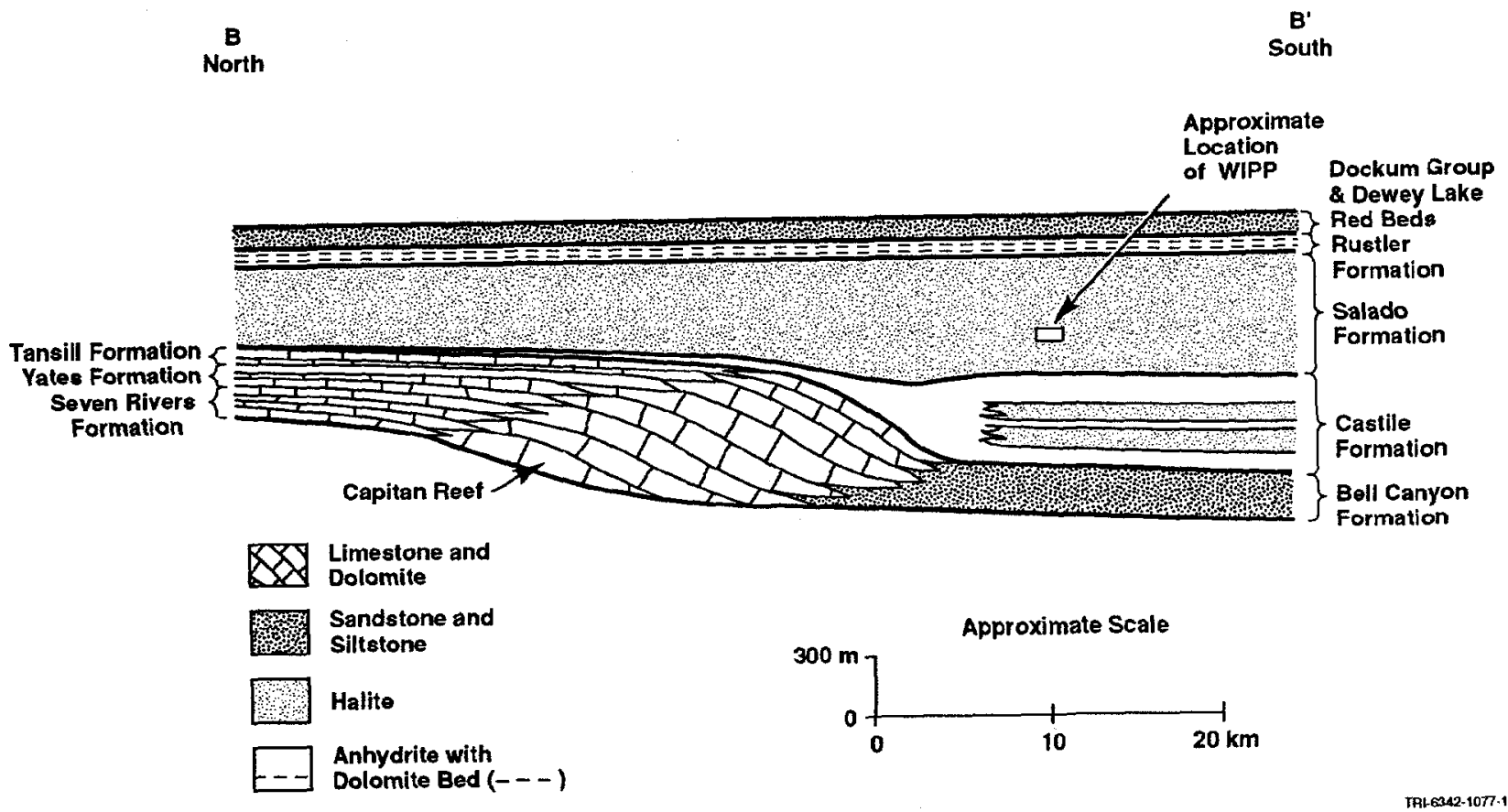

Figure 3. North-South geologic cross section through the Delaware Basin. Note extreme vertical exaggeration. Line of section is shown in Figure 1 (modified from Reference 13). 


\subsection{Geologic Processes Potentially Relevant to Long-Term Performance}

Because the relatively recent geologic past is believed to be a good predictor of the geologic future, characterization of repositories for long-lived radioactive waste has emphasized identification of processes active during the Quaternary Period (the last 1.6 million years) that might affect future performance of the disposal system. For the WIPP, geological investigations have concentrated on dissolution and deformation of the evaporites. These processes are discussed briefly here, together with tectonic activity, igneous activity, and climate change, which have been proposed as important processes for repositories in other geologic settings. (See Reference 3, Section 6.2 and Appendix SCR and also Reference 14, this volume, for a discussion of the systematic process followed to ensure that all significant processes, events, and features were considered in the performance assessment).

Dissolution. The present landscape of the Delaware Basin has been influenced by dissolution of the evaporites. Nash Draw, west of the site (Figure 1), is the largest karst feature in the region and was created by the near-surface dissolution of the upper portion of the Salado. Smaller sinkholes and subsidence features are present where evaporites are close to the surface. ${ }^{15}$ Some dissolution has also occurred at depth at the margins of the basin, where relatively fresh groundwater from the Capitan reef or other sources has come in contact with the evaporites.

Shallow dissolution of the upper Salado, such as has occurred beneath Nash Draw, has progressed from west to east across the Delaware Basin as a result of the regional tilting of the strata. The rate of dissolution is slow, however, and if dissolution in the future proceeds eastward at the same rate that it has in the past it will not affect the upper portion of the Salado at the site boundary for 225,000 years. An additional 2 to 3 million years would be required for dissolution to reach the repository horizon and expose the waste. ${ }^{3}$ These estimates are one to two orders of magnitude larger than the half-life of ${ }^{239} \mathrm{Pu}(24,000$ years) and substantially longer than the 10,000 -year regulatory period defined by the EPA (see Reference 16, this volume). Lateral encroachment of dissolution on the repository is, therefore, not considered in the performance assessment modeling.

Salt Deformation. Because salt flows in response to prolonged deviatoric stress, density contrasts between salt and the surrounding rock can result in deformation. In massive salt 
deposits, buoyancy effects may cause diapirism, in which salt rises through denser overlying units. In bedded salts that contain interbeds of more dense rocks, such as the anhydrites present in the Delaware Basin, gravity foundering of the interbeds may deform and displace the halite layers. Field exploration has shown that salt deformation is not present now at the WIPP site (although examples are present elsewhere in the basin), and rock mechanic modeling studies indicate that the rate at which salt could flow at the depths salt occurs at the WIPP $(0.0005 \mathrm{~m} / \mathrm{yr})^{17}$ is too slow to affect the repository during the next 10,000 years. $^{3}$

Tectonic activity. Regional uplift, such as that which caused the tilting of the Delaware Basin, operates too slowly to affect the performance of the repository. Projection of uplift rates from the past 10 million years indicates that changes over the next 10,000 years will be on the order of $1 \mathrm{~m}$, and will have only minor effects on other geologic processes such as erosion and dissolution. Active faults are not present in the interior of the Delaware Basin, and the repository will not be disrupted directly by faulting. Southeastern New Mexico is an area of low seismic activity and major earthquakes are not likely. Small-magnitude earthquakes do occur in the region and are anticipated to continue to occur in the future. Seismic effects on the waste-disposal region will be minor, however, and are accounted for in the performance assessment by the assumption that the waste is surrounded by a disturbed rock zone of relatively high permeability. ${ }^{3}$

Igneous activity. The most recent igneous activity in the Delaware Basin occurred approximately 35 million years ago, when magmatic intrusion resulted in emplacement of a vertical dike, or perhaps a set of dikes, that trend southwest-to-northeast across the basin. ${ }^{3}$ The geologic setting of the region in the continental interior, far removed from the nearest current igneous activity in the Rio Grande Rift of central New Mexico, makes the occurrence of igneous activity at the site during the next 10,000 years implausible.

Climate Change. The climate of southeastern New Mexico has changed repeatedly during the Quaternary in response to global cycles of glaciation. Conditions were coolest and wettest during glacial maxima when ice sheets covered much of northern North America. The hottest and driest conditions since the last glaciation have been similar to those of the present. Modeling of global circulation patterns suggests that these changes resulted from the disruption and southward displacement of the winter jet stream by the ice sheet, causing an increase in the frequency and intensity of winter storms throughout the American Southwest. ${ }^{18}$ Data from a variety of sources 
indicate that the mean annual precipitation at the WIPP 22,000 to 18,000 years ago, when the last North American ice sheet reached its southern limit roughly $1500 \mathrm{~km}$ north of the WIPP, was approximately twice that of the present. Mean annual temperatures may have been as much as $5^{\circ} \mathrm{C}$ colder than at present. ${ }^{19}$

Although a return to the extreme climatic conditions of full glaciation is improbable within the next 10,000 years, some degree of climate change is certain to occur. Paleoclimatic data indicate that precipitation in southeastern New Mexico may have approached glacial highs during relatively short-term (i.e., hundreds to thousands of years) climatic fluctuations at several times during the last 10,000 years. ${ }^{19}$

\section{Stratigraphy and Hydrostratigraphy at the WIPP Site}

Five rock units are modeled explicitly in the performance assessment: the Castile, Salado, and Rustler Formations, the Dewey Lake Red Beds, and the Triassic and younger rocks combined into a single layer. These units are shown in Figure 4, and described in more detail in the following sections.

\subsection{Castile Formation}

The Castile Formation is approximately $385 \mathrm{~m}$ thick at the WIPP and contains three thick anhydrite units separated by halite layers. ${ }^{17}$ Primary hydraulic conductivity of the Castile is extremely low, and the unit can appropriately be considered to be impermeable for the purposes of performance assessment modeling. However, oil and gas boreholes in the northeastern Delaware Basin have encountered brine within fractured anhydrite in the Castile at some locations (27 reported occurrences as of June 1996 [see Reference 3: Appendix MASS, Attachment MASS 186]). These "brine reservoirs" are located in areas of structural deformation within the Castile, and brine is believed to occur primarily in vertical or near-vertical fractures. Reservoirs typically occur in the upper portion of the Castile, and can contain large volumes of brine. The closest known reservoir to the repository, encountered at the WIPP-12 borehole within the site boundary north of the disposal region, is at a depth of $918 \mathrm{~m}$ (about $250 \mathrm{~m}$ below the repository horizon), and is estimated to contain $2.7 \times 10^{6} \mathrm{~m}^{3}$ of brine. Fluid pressures can be high: pressure in the WIPP-12 reservoir was measured at $12.7 \mathrm{MPa}$ (compared to the nominal hydrostatic pressure of $11.1 \mathrm{MPa}$ expected for a column of brine at that depth), and brine flowed to the surface during drilling. ${ }^{20}$ 


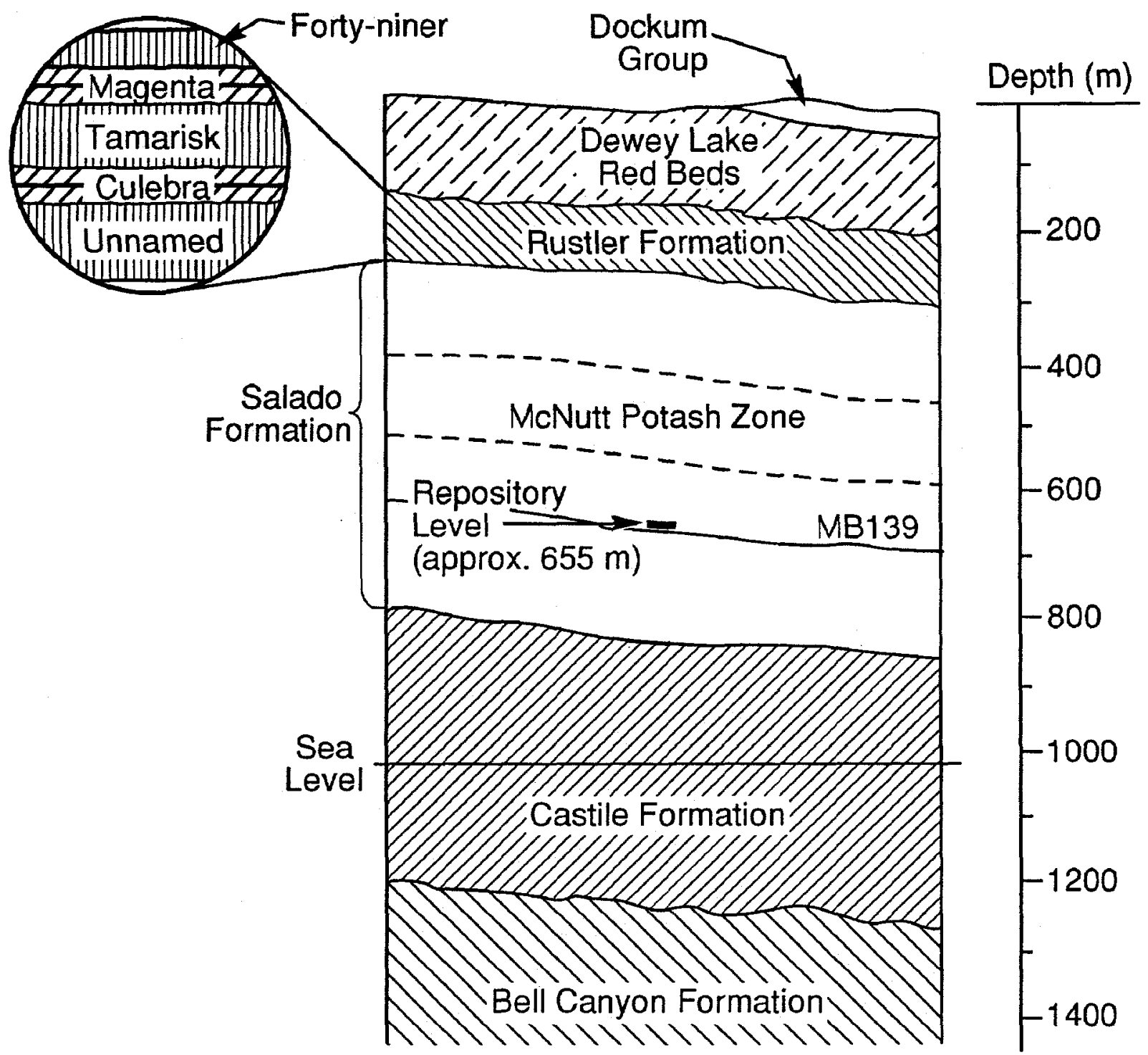

TRL6801-97-0

Figure 4. Generalized stratigraphy of the Late Permian and younger rocks at the WIPP site (modified from Reference 10).

Geochemical analysis of Castile brine from the WIPP-12 borehole and the ERDA- 6 borehole northeast of the site indicates that the most likely source of the brine is ancient (Permian-age) seawater. ${ }^{20}$ There is no evidence for fluid contribution from modern meteoric waters. Brine chemistries from the ERDA-6 and WIPP-12 reservoirs are distinctly different from each other and from local groundwaters, and the reservoirs are apparently hydraulically isolated. The brines are saturated, or nearly so, with respect to halite and, consequently, have little potential to migrate through the evaporites by dissolution processes. 
Although structural conditions associated with brine reservoirs are not present directly beneath the repository, the presence of a reservoir below the disposal region cannot be ruled out. A brine reservoir below the waste would have no affect on the disposal system as long as it remained undisturbed, but future drilling activity could possibly result in an inadvertent borehole penetration of both the repository and an underlying reservoir. Performance assessment modeling, therefore, includes the possible existence of a brine reservoir (see Reference 21, this volume). The probability that a borehole through the repository will penetrate a brine reservoir is set at 0.08 , based on a statistical analysis of the distribution of known brine encounters in the region (see Reference 3: Appendix MASS, Attachment MASS 18-6). Simulated brine volumes produced by the hypothetical reservoir beneath the repository are consistent with well data, primarily from the WIPP-12 and ERDA- 6 encounters.

\subsection{Salado Formation}

The Salado Formation is about $600 \mathrm{~m}$ thick at the WIPP and is divided into three informal members. The middle member, known locally as the McNutt Potash Zone, includes 10 ore zones significant because of their high concentrations of potassium salts. The lower and upper members remain unnamed. The WIPP repository level is located below the McNutt in the lower member.

Depositional processes that created the Salado were laterally persistent over large areas, and individual stratigraphic horizons within the formation can be recognized in potash mines and boreholes throughout the area. ${ }^{22}$ Forty-four anhydrite and polyhalite "marker beds" in the Salado have been identified and numbered in the region. ${ }^{23}$ Thinner interbeds of anhydrite, clay, and polyhalite occur throughout the formation and are also laterally persistent. As shown in Figure 5, the waste disposal region is excavated within an approximately $7 \mathrm{~m}$-thick section of halite and polyhalite between anhydrite marker beds 138 (MB138) and 139 (MB139). MB139, which is approximately $0.85 \mathrm{~m}$ thick, lies about $1.4 \mathrm{~m}$ below the floor of the excavation. MB138, which is approximately $0.18 \mathrm{~m}$ thick, lies approximately $12 \mathrm{~m}$ above the excavation. Two thinner anhydrite interbeds, informally named anhydrites a and $b$, occur between the excavation and MB138. 


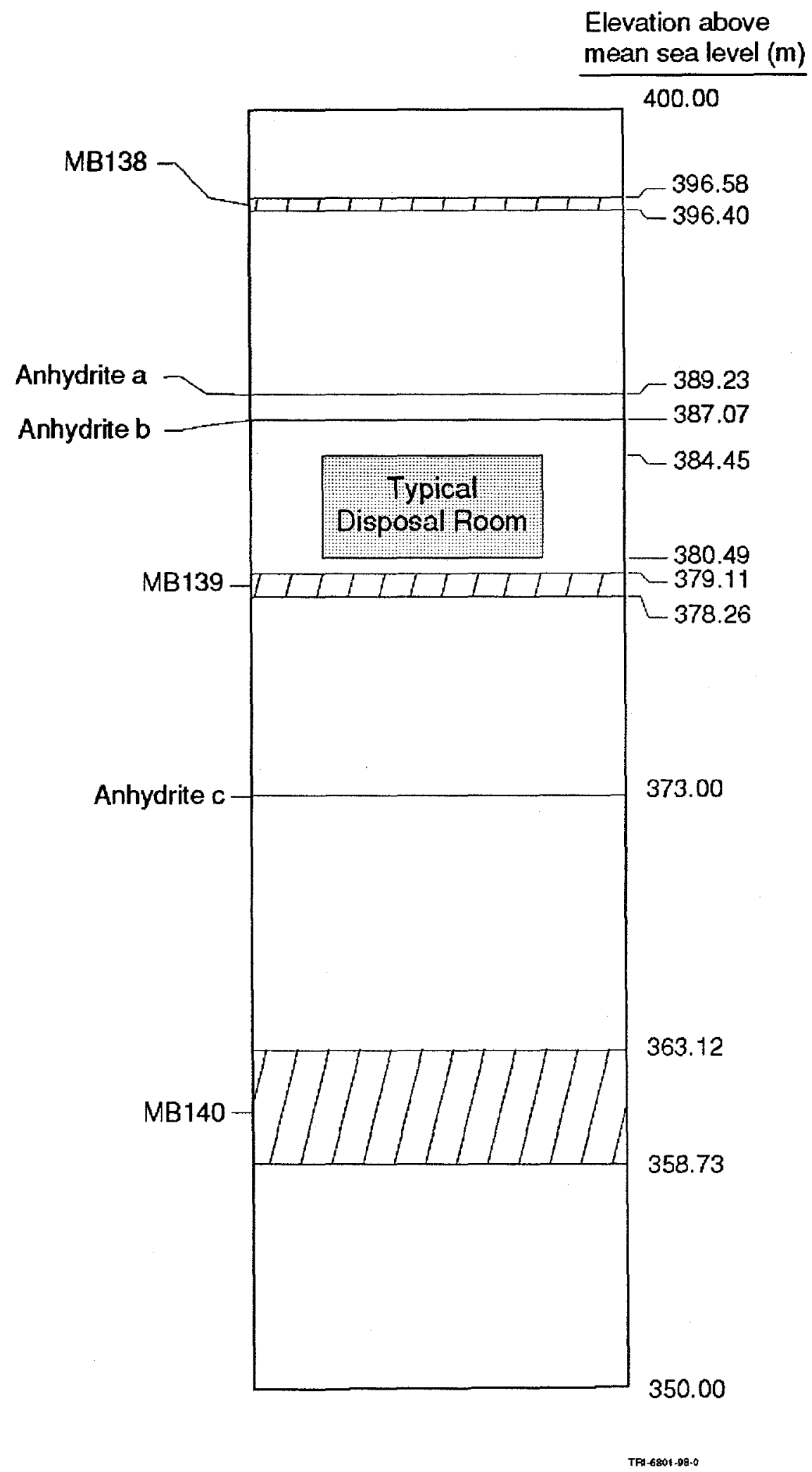

Figure 5. Detailed stratigraphy of the Salado Formation at the repository horizon (modified from Reference 10). 
Hydraulic testing in the Salado in boreholes in the WIPP underground provided quantitative estimates of the hydraulic properties controlling brine flow through the Salado halite. ${ }^{24,25,26}$ Twenty-two hydraulic tests have been performed in impure halite and two in pure halite. Interpreted values of hydraulic conductivity vary from $10^{-16}$ to $10^{-11} \mathrm{~m} / \mathrm{s}$ for impure halite intervals. Interpreted formation pore pressures vary from 0.3 to $9.7 \mathrm{MPa}$ for impure halite, with the lower pressures showing effects of enhanced hydraulic conductivity in a disturbed rock zone (DRZ) surrounding the excavation. Tests in pure halite show no observable response, indicating either extremely low hydraulic conductivity $\left(<10^{-16} \mathrm{~m} / \mathrm{s}\right)$, or no flow whatsoever, even though appreciable pressure gradients are applied.

Fourteen hydraulic tests have been performed in anhydrite. Interpreted values of hydraulic conductivity vary from $10^{-13}$ to $10^{-10} \mathrm{~m} / \mathrm{s}$, and interpreted formation pore pressures vary from atmospheric to $12.5 \mathrm{MPa}{ }^{25}$ Lower values are caused by depressurization near the excavation. Additional data on anhydrite properties are available from laboratory tests on core samples, and both laboratory and field data were used to establish parameter values for performance assessment modeling (see Reference 3, Appendix PAR).

Although the hydraulic conductivity of the Salado is extremely low, the formation is not dry. Brine content within the Salado is estimated at 1 to $2 \%$ by weight, and thin clay seams have been observed to contain up to $25 \%$ brine by volume. ${ }^{27}$ Brine seepage into the excavated region has been estimated at $0.01 \mathrm{~L} /$ day for each meter of tunnel length. ${ }^{28}$ This rate of flow will decrease in the future when the repository is sealed and hydraulic gradients decrease, and brine flow in the performance assessment is a calculated term dependent on local hydraulic gradients and properties of the Salado units (see Reference 21, this volume).

\subsection{Rustler Formation}

The Rustler is $95 \mathrm{~m}$ thick at the WIPP and is composed of anhydrite, halite, siltstone and sandstone, and dolomite. On the basis of outcrops in Nash Draw west of the WIPP, the formation is divided into four formally named members and a lower unnamed member. ${ }^{29}$ These five units are, in ascending order, the unnamed lower member (oldest), the Culebra Dolomite Member, the Tamarisk Member, the Magenta Dolomite Member, and the Forty-niner Member (youngest) (Figure 4). 
The unnamed lower member rests on the Salado with apparent conformity at the WIPP site. The lower portion of the unit contains claystones and siltstones that record the transition from strongly evaporative environments of the Salado to saline lagoonal environments. The upper part of the unnamed lower member includes halitic and sulfatic beds within clastics. ${ }^{30}$ Tests of claystones and siltstones in the lower portion of the unit indicate that hydraulic conductivity ranges from $10^{-14}$ to $10^{-11} \mathrm{~m} / \mathrm{s}$. Hydraulic conductivity in the lower portion of the unnamed lower member increases to the west in and near Nash Draw, where dissolution at the underlying Rustler-Salado contact has caused subsidence and fracturing of the siltstone.

The Culebra is a microcrystalline dolomite or dolomitic limestone that ranges in thickness in the WIPP region from 4 to $11.6 \mathrm{~m} .^{29,31}$ It has been identified as the most likely pathway for subsurface release of radionuclides from the repository following a borehole intrusion, and hydrologic research has concentrated on the unit since the $1970 \mathrm{~s}^{31,32,33,34,35,36,37,38}$ Hydraulic data are available from 43 well locations in the WIPP vicinity. ${ }^{3,31}$ Tracer tests conducted at six locations provide data about the transport of nonsorbing tracers through the unit. ${ }^{3,38,39}$ Laboratory tests using core samples from Culebra and pure dolomite provide data about sorption of radionuclides during transport. ${ }^{3}$

Hydraulic conductivity of the Culebra varies six orders of magnitude from east to west in the region of the site, ranging from about $10^{-10} \mathrm{~m} / \mathrm{s}$ east of the WIPP to $10^{-4} \mathrm{~m} / \mathrm{s}$ in Nash Draw. These conductivity variations are believed to be controlled by the relative abundance of open fractures rather than by primary depositional features of the unit. Qualitative correlations have been noted between hydraulic conductivity and several geologic features possibly related to the density of open fractures, including the distribution of overburden above the Culebra, the dissolution of halite in the upper portion of the Salado, and the distribution of gypsum fillings in fractures in the Culebra. $^{3}$ Porosity of the Culebra, as measured in core samples, also has a large range, from 0.03 to $0.30^{3}$

The Tamarisk is about $36 \mathrm{~m}$ thick at the WIPP, and consists of mostly anhydrite or gypsum with interbedded claystone and siltstone. East of the repository, halite is present in the middle portion of the unit, laterally equivalent to the claystone layer at the site. The thickness of the Tamarisk varies considerably throughout the region (from 8 to $84 \mathrm{~m}$ ), primarily as a function of the thickness of halite in the middle portion, which is interpreted as having been deposited in localized 
salt pans. ${ }^{30}$ The Tamarisk has extremely low hydraulic conductivity. Hydraulic tests have been attempted in the Tamarisk at only two locations and in both wells hydraulic conductivity proved to be too low to measure in the time allowed. Based on these incomplete tests, hydraulic conductivity of the most permeable portion of the Tamarisk, the middle claystone and siltstone, is estimated to be one or more orders of magnitude less than that of a tested interval containing siltstone in the unnamed lower member (that is, less than $10^{-11} \mathrm{~m} / \mathrm{s}$ ). ${ }^{34}$ The porosity of the Tamarisk was measured in core from the H-19 hydropad. Two claystone samples had effective porosities of 21.3 and $21.7 \%$. Five anhydrite samples had effective porosities of 0.2 to $1.0 \%{ }^{3}$

The Magenta is about $8 \mathrm{~m}$ thick at the WIPP and consists of a fine-grained gypsiferous dolomite. Although less transmissive than the Culebra, the Magenta does produce water in wells. Hydraulic data from 15 locations suggest that hydraulic conductivity ranges over five orders of magnitude from $10^{-10}$ to $10^{-5} \mathrm{~m} / \mathrm{s}^{33}$ Effective porosities measured in core samples range from 2.7 to $25.2 \%{ }^{3}$ In most locations, the hydraulic conductivity of the Magenta is one to two orders of magnitude less than that of the Culebra, and variability follows the same trend as in the Culebra, with conductivity increasing to the west.

The Forty-niner is about $20 \mathrm{~m}$ thick throughout the WIPP area and consists of low-permeability anhydrite and siltstone. Hydraulic tests at two locations yielded values of hydraulic conductivity ranging from $10^{-10}$ to $10^{-9} \mathrm{~m} / \mathrm{s} .{ }^{34}$ Three claystone core samples had effective porosities ranging from 9.1 to $24.0 \%$. Four anhydrite samples had effective porosities ranging from 0.0 to $0.4 \%$.

\subsection{The Dewey Lake Red Beds}

The Dewey Lake consists predominantly of reddish-brown fine sandstone, siltstone, and silty claystone, and is approximately $150 \mathrm{~m}$ thick in the center of the WIPP site. ${ }^{40,41}$ The formation is thicker to the east of the WIPP site, in part because western areas were eroded before the overlying Triassic rocks were deposited.

The Dewey Lake contains a saturated and transmissive zone in the southwestern to south-central portion of the WIPP site and south of the site. The transmissive zone occurs in the upper portion of the unit, 50 to $80 \mathrm{~m}$ below the ground surface, and appears to derive much of its hydraulic conductivity from open fractures. Fractures below the transmissive zone tend to be completely filled with gypsum. Open fractures and/or moist (but not fully saturated) conditions have been 
observed at similar depths north of the transmissive zone, in the immediate vicinity of the repository. Elevation of the water table at the WIPP is estimated for performance assessment modeling to be $980 \mathrm{~m}$ above mean sea level, approximately $60 \mathrm{~m}$ below the land surface. ${ }^{3}$ Effective porosity, measured in four core samples taken above the zone in which fractures are filled with gypsum, ranged from 14.9 to $24.8 \%$. Four samples taken from within the gypsumsealed region had porosities from 3.5 to $11.6 \%{ }^{3}$

\subsection{Near-Surface Rocks}

Near-surface rocks younger than the Dewey Lake Red Beds are thin at the WIPP. The Triassicage Santa Rosa Formation is absent west of the WIPP due to erosion, and is less than $8 \mathrm{~m}$ thick above the repository. East of the site boundary, the formation contains up to $90 \mathrm{~m}$ of coarsegrained sandstones and conglomerates, and is locally a productive source of groundwater. The Santa Rosa is overlain at the WIPP by $4 \mathrm{~m}$ of sandstones of the latest Tertiary and Quaternary-age Gatuña Formation, which is present in varying thicknesses throughout the region. ${ }^{10,41}$

\section{Natural Resources}

Natural resources in the vicinity of the WIPP are potentially important to long-term performance of the site because they may affect future human activities that could disrupt the disposal system. Groundwater, hydrocarbons, and potash (potassium salts used for industrial and agricultural purposes) are described here. Less important resources that are unlikely to be exploited near the site, including road gravel, salt, gypsum, and sulfur, are discussed in the Compliance Certification Application. $^{3}$

\subsection{Groundwater}

Four geologic units in the WIPP area possess groundwater that apparently meets the definition of an Underground Source of Drinking Water (USDW) under EPA regulations: (a) the Capitan Aquifer (which includes the Capitan Reef and associated rocks), (b) the Culebra, (c) the Dewey Lake, and (d) the Santa Rosa (see Reference 3, Appendix USDW).

Where present, the Capitan is capable of producing a significant quantity of water: for example, the Capitan is the primary source of water for the City of Carlsbad, with wells that produce up to 
$15 \mathrm{~m}^{3} / \mathrm{min}(4,000 \mathrm{gal} / \mathrm{min})$. The Capitan is not present at the WIPP, however, and has no role in the long-term performance of the disposal system.

Seven wells in the WIPP vicinity produce groundwater from the Culebra that meets the minimum EPA standards of producing at least $0.02 \mathrm{~m}^{3} / \mathrm{min}(5 \mathrm{gal} / \mathrm{min})$ of water containing less than $10,000 \mathrm{mg}$ of total dissolved solids per liter. Three of these wells, all south of the WIPP, are private wells that currently supply water for livestock. Water quality is relatively poor in all seven wells $(2,100$ to $8,890 \mathrm{mg} / \mathrm{L})$, and none produce water for human consumption.

Six wells in the region have produced water meeting EPA standards from the Dewey Lake. Five of these wells produce water for livestock, and water from one, located $5.5 \mathrm{~km}$ south of the disposal region, has supplied water for a single residence. None of these wells are known to have produced at rates exceeding approximately $0.1 \mathrm{~m}^{3} / \mathrm{min}$ ( $30 \mathrm{gal} / \mathrm{min}$ ), and water quality is relatively poor, with total dissolved solids reported to be $3,330 \mathrm{mg} / \mathrm{L}$ or higher. Two wells 12 to $15 \mathrm{~km}$ east of the WIPP produce relatively good quality water ( 340 and $780 \mathrm{mg} / \mathrm{L}$ total dissolved solids) from the Santa Rosa, but the formation is thin or absent closer to the site and does not produce water in wells above the disposal region.

\subsection{Hydrocarbon Resources}

The Delaware Basin and surrounding region contain major oil and gas resources that have been exploited on a large scale since the 1920s. Historically, most hydrocarbons have been found outside the basin in carbonates and sandstones deposited behind the Capitan reef, but both natural gas and oil have been found in sediments below the evaporites in the interior of the basin. In the immediate vicinity of the WIPP, natural gas is produced from Pennsylvanian-age sandstones and limestones at depths ranging from 3600 to $4600 \mathrm{~m} .^{42}$ Oil is produced from sandstone and carbonate reservoirs in the Bone Spring, Brushy Canyon, and Cherry Canyon Formations at depths ranging from 1,680 to $3,360 \mathrm{~m}$. Oil is also found elsewhere in the region in the Bell Canyon Formation directly below the evaporites. The Bell Canyon is unproductive near the WIPP, and is used for disposal of salt water at a depth of approximately $1400 \mathrm{~m}$.

Drilling for both exploration and production is prohibited within the $41.4 \mathrm{~km}^{2}\left(16 \mathrm{mi}^{2}\right)$ controlled area surrounding the WIPP, but numerous boreholes have been drilled in the surrounding region. Drilling for oil is currently active in the region and is likely to continue in the near future, as 
existing reservoirs are exploited and new ones are discovered. Drilling for oil and gas beneath the site, which might occur if knowledge of the WIPP were lost, could result in a breach of the repository. For the purposes of performance assessment, the EPA has required that drilling at the WIPP be assumed to continue for the next 10,000 years at the same rate that it has occurred in the last 100 years in the entire Delaware Basin. ${ }^{43}$ The DOE has identified 10,804 deep boreholes within the $23,100 \mathrm{~km}^{2}$ area of the Delaware Basin and, therefore, has calculated a drilling rate of 46.8 boreholes $/ \mathrm{km}^{2} / 10,000 \mathrm{yr}$ for use in the performance assessment (see Reference 3, Appendix DEL). See Reference 44, this volume, for a discussion of the use of this drilling rate in the performance assessment.

\subsection{Potash Resources}

Two potassium salts, sylvite $(\mathrm{KCl})$ and langbeinite $\left(\mathrm{K}_{2} \mathrm{Mg}_{2}\left(\mathrm{SO}_{4}\right)_{3}\right)$, are found in the $\mathrm{McNutt}$ member of the Salado above the repository horizon. Ore-grade deposits are found in 10 layers, or ore zones, within a region known as the Carlsbad Potash District. Approximately $400 \mathrm{~km}^{2}$ of the potash district, including land immediately adjacent to the WIPP site, are currently leased by mining companies, and several large underground mines are active in the region. Ore is not present directly above the waste disposal region and mining is forbidden within the controlled area surrounding the WIPP, but economically minable ore is present in two horizons within the controlled area. The EPA has required that performance assessments assume that this ore may be mined at some time in the future, and that the effects of mining on groundwater flow in the Culebra be incorporated in the analysis. ${ }^{43}$ See Reference 45 , this volume, for a discussion of the treatment of mining in the performance assessment.

\section{Groundwater Flow and Radionuclide Transport in Strata above the Salado Formation}

The bedded salt of the Salado Formation is the primary geologic barrier to migration of radionuclides from the WIPP repository. Performance assessment results indicate that no radionuclides will migrate vertically through the salt to overlying strata if the repository remains undisturbed by human intrusion (see Reference 46, this volume). However, the site characterization process and the performance assessment have considered intrusion scenarios that 
result in upward migration of radionuclides through abandoned boreholes. This section summarizes groundwater movement and processes that could affect radionuclide transport in strata that overlie the Salado.

The conceptual understanding of regional groundwater flow ${ }^{47}$ used to support performance assessment models of transport in strata above the Salado is referred to as the groundwater basin model. ${ }^{3}$ According to this conceptualization, a single groundwater flow system extends upward from the top of the Salado to the land surface. Rock units described in the previous section can be viewed, in the context of regional groundwater flow, as alternating layers of conductive (relatively more permeable) units and confining (relatively less permeable) units. The conductive units are, from top to bottom, the Dewey Lake Red Beds and overlying Triassic rocks, the Magenta dolomite, and the Culebra dolomite. The confining layers are the Forty-niner, Tamarisk, and unnamed members. Groundwater flow above the Salado is characterized by very slow downward leakage through confining units and faster lateral flow in conductive units. Of the conductive units, the Culebra is the most transmissive, has the lowest hydraulic head, and the fastest groundwater flow. Consequently, the Culebra would receive most of the contaminated brine that would flow up a borehole that had penetrated the repository and would provide the most rapid lateral groundwater flow path toward the accessible environment. Groundwater flow in the strata above the Salado is driven by the relief of the water table in the Dewey Lake Red Beds. The position of the water table is determined by an interplay of recharge rates and the topography of the land surface. Changes in climate can alter speeds and directions of groundwater flow in units above the Salado by changing recharge rates.

Groundwater flow in this system has been simulated using a three-dimensional, transient, regionalscale model. ${ }^{47}$ Simulation results suggest that infiltrating water first flows downward and laterally in the uppermost conductive unit, the Dewey Lake and Triassic rocks. The direction of lateral flow in this unit is from regions where the water table is at a high elevation to regions where it is lower. This direction has been generally from east to west for the last several tens of thousands of years. A small portion of the groundwater flowing at the base of the Dewey Lake is refracted downward and into the less conductive Forty-niner Member. This groundwater flows extremely slowly downward through the Magenta and Tamarisk until it reaches the Culebra, where it joins groundwater flowing laterally, and more rapidly, through this more conductive unit. Simulation 
results suggest that it takes a few tens of thousands of years for groundwater to travel from a recharge area about $15 \mathrm{~km}$ northeast of the WIPP site to the Culebra within the western portion of the site. Radiocarbon model ages of Culebra groundwaters ${ }^{48}$ support this travel time.

Regional-scale modeling was also used to examine the possible effects of climate change on rates of groundwater flow in the Culebra. ${ }^{47}$ Simulation results suggest that flow in the Culebra is still adjusting (slowing down) in response to a decrease in precipitation ${ }^{19}$ that occurred at the WIPP site between about 14,000 and 8,000 years ago. Superimposed on the long-term slowing of flow rates are shorter periods of relatively faster flow. Simulations of possible effects of climate changes during the next 10,000 years examined conditions in which the recharge pattern of the past 8,000 years continued essentially unchanged and conditions in which recharge rates increased sufficiently to raise the water table to the land surface. Even in the latter case, which is a limiting condition hydrologically and corresponds to a highly unlikely return to a wet, full-glacial climate in North America within the next 10,000 years, simulated flow rates in the Culebra do not increase by more than a factor of about two. Results of simulations of different future recharge conditions were used to support a distribution for a sampled parameter that scaled (increased) flow rates for performance assessment models of groundwater flow in the Culebra (see Reference 45, this volume) to account for possible effects of future climate change.

Groundwater flow in the Culebra in the vicinity of the site is predominantly from north to south, and is much more rapid in more transmissive regions west of the site. Calibration of flow fields based on hydraulic test data indicate that flow from potential release points above the disposal region to the site boundary is toward the southeast and south, following a local zone of high hydraulic conductivity that enters the site from the south., ${ }^{35,37}$

Flow along this path occurs within fractures, within vugs (small cavities) where they are connected by fractures, and, to some extent, within interparticle porosity where hydraulic conductivity is high, such as in chalky lenses. ${ }^{49}$ When the contrast in hydraulic conductivity between different scales of connected porosity is large, the total porosity can effectively be conceptualized by dividing the system into advective porosity (often referred to as fracture porosity) and diffusive porosity (often referred to as matrix porosity). The advective porosity is defined as the portion of the porosity where flow is the dominant process. Diffusive porosity is defined as the portion of the porosity where diffusion is the dominant transport process. Where the hydraulic conductivity 
of the fractures is significantly larger than the conductivity of the other porosity types, advective porosity is predominantly fracture porosity and is small. Where conductivity contrasts between porosity types are small, due to a lack of large fractures or the presence of gypsum fillings in a portion of the porosity, the advective porosity is a combination of fractures, vugs connected by fractures, and permeable portions of the interparticle porosity.

The major physical transport processes that affect actinide transport through the Culebra include advection (through advective porosity), diffusion from the advective porosity into the diffusive porosity, and dispersive spreading due to heterogeneity. Diffusion can be an important process for effectively retarding solutes by transferring mass from the porosity where advection is the dominant process into other portions of the rock. Diffusion into stagnant portions of the rock also provides access to additional surface area for sorption. A further discussion of transport of actinides in the Culebra as either dissolved species or as colloids is given in Section 6.4.6.2 of the Compliance Certification Application ${ }^{3}$ and in Reference 45, this volume.

Sorption of radionuclides onto minerals in the Culebra dolomite is an important chemical process that slows transport of contaminants toward the accessible environment. The two most important sorbents in the Culebra are dolomite, a carbonate mineral that constitutes most of the Culebra, and the clay mineral corrensite, an ordered mixture of chlorite and saponite associated with fracture surfaces and dispersed in the rock matrix of the Culebra (see Reference 3, Appendix

MASS.15.2.1). Dolomite is important because it is by far the most abundant mineral in the Culebra. Corrensite is important because, although a minor constituent, it sorbs actinide elements more strongly than dolomite. However, the DOE does not include sorption onto corrensite in performance assessment calculations because laboratory data for clay-rich rock under expected Culebra conditions are insufficient at this time.

\section{Summary of the Natural Barriers Contributing to Radionuclide Isolation at the WIPP}

The bedded salt of the Salado Formation is the first, and most important, component of the geologic barriers that will isolate radionuclides at the WIPP. The extremely low permeability of the halite layers within the Salado precludes vertical flow of contaminated brine from the repository, and lateral flow within the somewhat more permeable anhydrite interbeds will be slow. 
Performance assessment results indicate that, if the repository is undisturbed by human intrusion, no radionuclides will migrate vertically through the salt during the next 10,000 years, and lateral transport in interbeds will be insignificant (see Reference 46 , this volume).

If the repository is inadvertently penetrated by future drilling operations, the borehole could provide a pathway for radionuclide transport through the salt section into overlying strata. If this occurs, geologic and hydrologic properties of the overlying rocks will contribute to the continuing isolation of the radionuclides from the biosphere. Field studies indicate that subsurface transport away from the site is most likely to occur in the Culebra dolomite, where physical and chemical retardation processes will prevent unacceptable quantities of radionuclides from crossing the site boundary within the next 10,000 years. ${ }^{46}$ The poor quality of groundwater in the region provides further confidence that even if groundwater should become contaminated following a borehole intrusion into the repository, prolonged human exposure is unlikely.

\section{Acknowledgments}

Portions of this paper are based on the WIPP Compliance Certification Application, ${ }^{3}$ which included contributions from numerous project scientists and engineers. We thank all of those whose work over the past 24 years made this summary possible. We specifically thank Rick Beauheim for this technical review of this paper, Dave Bullock for his quality assurance review, and Mel Marietta for his management review. Work on this paper was supported by the U.S. Department of Energy under Contract DE-AC04-94-AL8500 with Sandia National Laboratories (SNL). SNL is operated by Sandia Corporation, a Lockheed Martin Company.

\section{References}

1. Rechard et al. 1998. (this volume)

2. Hansen et al. 1998. (this volume) 
3. United States Department of Energy, 1996, Title 40 CFR Part 191 Compliance Certification Application for the Waste Isolation Pilot Plant, DOE/CAO-19962184, United States Department of Energy, Carlsbad Area Office, Carlsbad, NM.

4. Powers, D.W., Lambert, S.J., Shaffer, S.-E., Hill, L.R., and Weart, W.D., eds., 1978, Geological Characterization Report, Waste Isolation Pilot Plant (WIPP) Site, Southeastern New Mexico, SAND78-1596, Sandia National Laboratories, Albuquerque, NM.

5. Hills, J.M., 1984, "Sedimentation, Tectonism, and Hydrocarbon Generation in the Delaware Basin, West Texas and Southeastern New Mexico," American Association of Petroleum Geologists Bulletin, vol. 68, no. 3, 250-267.

6. Ward, R.F., Kendall, C.G.St.C., and Harris, P.M., 1986, "Upper Permian (Guadalupian) Facies and Their Association with Hydrocarbons-Permian Basin, West Texas and New Mexico," American Association of Petroleum Geologists Bulletin, vol. 70, no. $3,239-262$.

7. Harms, J.C., and Williamson, C.R., 1988, "Deep-Water Density Current Deposits of Delaware Mountain Group (Permian), Delaware Basin, Texas and New Mexico," American Association of Petroleum Geologists Bulletin, vol. 72, no. 3, 299-317.

8. Frenzel, H.N., Bloomer, R.R., Cline, R.B., Cys, J.M., Galley, J.E., Gibson, W.R., Hills, J.M., King, W.E., Seager, W.R., Kottlowski, F.E., Thompson, S., III., Luff, G.C., Pearson, B.T., and Van Siclen, D.C., 1988, "The Permian Basin Region," in Sloss, L.L., ed., Sedimentary Cover-North American Craton: U.S., The Geology of North America Volume D-2, Geological Society of America, Boulder, CO, p. 261-306.

9. Palmer, A.R., 1983, “The Decade of North American Geology 1983 Geologic Time Scale," Geology, vol. 11, no. 9, pp. 503-504.

10. WIPP Performance Assessment Department, 1992-1993, Preliminary Performance Assessment for the Waste Isolation Pilot Plant, December 1992: Volumes 1-5, SAND92-0700/1-5, Sandia National Laboratories, Albuquerque, NM. 
11. Hawley, J.W., 1993, "The Ogallala and Gatuña Formations in the Southeastern New Mexico Region, A Progress Report," in Carlsbad Region, New Mexico and West Texas, New Mexico Geological Society Forty-Fourth Annual Field Conference, October 6-9, 1993, New Mexico Geological Society, Socorro, NM, p. 261-269.

12. Powers, D.W., and Holt, R.M., 1993, "The Upper Cenozoic Gatuña Formation of Southeastern New Mexico," in Carlsbad Region, New Mexico and West Texas, New Mexico Geological Society Forty-Fourth Annual Field Conference, October 69, 1993, New Mexico Geological Society, Socorro, NM, p. 271-282.

13. Davies, P.B., 1984, "Deep-Seated Dissolution and Subsidence in Bedded Salt Deposits," Unpublished Ph.D. dissertation, Department of Applied Earth Sciences, Stanford University, Stanford, CA.

14. Galson et al. 1998. (this volume)

15. Bachman, G.O., 1987, Karst in Evaporites in Southeastern New Mexico, SAND867078, Sandia National Laboratories, Albuquerque, NM.

16. Howard et al., 1998. ([Regulatory paper] this volume)

17. Borns, D.J., Barrows, L.J., Powers, D.W., and Snyder, R.P., 1983, Deformation of Evaporites Near the Waste Isolation Pilot Plant (WIPP) Site, SAND82-1069, Sandia National Laboratories, Albuquerque, NM.

18. COHMAP (Cooperative Holocene Mapping Project) Members, 1988, "Climatic Changes of the Last 18,000 Years: Observations and Model Simulations," Science, vol. 241 , no. 4869 , p. $1043-1052$.

19. Swift, P.N., 1993, "Long-Term Climate Variability at the Waste Isolation Pilot Plant, Southeastern New Mexico, USA," Environmental Management, vol. 17, no. 1, p. 83-97. 
20. Popielak, R.S., Beauheim, R.L., Black, S.R., Coons, W.E., Ellingson, C.T., and Olsen, R.L., 1983, Brine Reservoirs in the Castile Formation, Waste Isolation Pilot Plant (WIPP) Project, Southeastern New Mexico, TME-3153, United States Department of Energy, Carlsbad, NM.

21. Vaughn et al. 1998. (this volume)

22. Lowenstein, T.K., 1988, "Origin of Depositional Cycles in a Permian "Saline Giant": The Salado (McNutt Zone) Evaporites of New Mexico and Texas," Geological Society of America Bulletin, vol. 100, no. 4, p. 592-608.

23. Jones, C.L., Bowles, C.G., and Bell, K.G., 1960, Experimental Drill Hole Logging in Potash Deposits of the Carlsbad District, New Mexico, United States Geological Survey Open File Report 60-84, United States Geological Survey, Denver, CO.

24. Beauheim, R.L., Roberts, R.M., Dale, T.F., Fort, M.D., and Stensrud, W.A., 1993, Hydraulic Testing of Salado Formation Evaporites at the Waste Isolation Pilot Plant Site: Second Interpretive Report, SAND92-0533, Sandia National Laboratories, Albuquerque, NM.

25. Beauheim, R.L., Saulnier, Jr., G.J., and Avis, J.D., 1991, Interpretation of BrinePermeability Tests of the Salado Formation at the Waste Isolation Pilot Plant Site: First Interim Report, SAND90-0083, Sandia National Laboratories, Albuquerque, NM.

26. Domski, P.S., Upton, D.T., and Beauheim, R.L., 1996, Hydraulic Testing Around Room Q: Evaluation of the Effects of Mining on the Hydraulic Properties of Salado Evaporites, SAND96-0435, Sandia National Laboratories, Albuquerque, NM.

27. Deal, D.E., Abitz, R.J., Myers, J., Belski, D.S., Martin, M.L., Milligan, D.J., Sobocinski, R.W., and Lipponer, P.P.J., 1993, Brine Sampling and Evaluation Program, 1991 Report, DOE-WIPP-93-026, Westinghouse Electric Corporation, Carlsbad, NM. 
28. Bredehoeft, J.D., 1988, "Will Salt Repositories Be Dry?" EOS, Transactions of the American Geophysical Union, vol. 69, no. 9, p. 121, 131.

29. Vine, J.D., 1963, Surface Geology of the Nash Draw Quadrangle, Eddy County, New Mexico, United States Geological Survey Bulletin 1141-B, United States Geological Survey, Washington, DC.

30. Holt, R.M., and Powers, D.W., 1988, Facies Variability and Post-Depositional Alteration Within the Rustler Formation in the Vicinity of the Waste Isolation Pilot Plant, Southeastern New Mexico, DOE/WIPP-88-004, Westinghouse Electric Corporation, Carlsbad, NM. (Also republished as Appendix FAC of Reference 3, DOE, 1996.)

31. Cauffman, T.L., LaVenue, A.M., and McCord, J.P., 1990, Ground-Water Flow Modeling of the Culebra Dolomite: Volume II: Data Base, SAND89-7068/2, Sandia National Laboratories, Albuquerque, NM.

32. Mercer, J.W., and Orr, B.R., 1977, Review and Analysis of Hydrogeologic Conditions Near the Site of a Potential Nuclear-Waste Repository, Eddy and Lea Counties, New Mexico, United States Geological Survey Open-File Report 77-123, United States Geological Survey, Albuquerque, NM.

33. Mercer, J.W., 1983, Geohydrology of the Proposed Waste Isolation Pilot Plant Site, Los Medaños Area, Southeastern New Mexico, United States Geological Survey Water-Resources Investigations Report 83-4016, United States Geological Survey, Albuquerque, NM. (Also published as Appendix HYDRO of Reference 3, DOE, 1996).

34. Beauheim, R.L., 1987, Interpretations of Single-Well Hydraulic Test Conducted At and Near the Waste Isolation Pilot Plant (WIPP) Site, 1983-1987, SAND87-0039, Sandia National Laboratories, Albuquerque, NM.

35. LaVenue, A.M., Cauffman, T.L., and Pickens, J.F., 1990, Ground-Water Flow Modeling of the Culebra Dolomite: Volume I - Model Calibration, SAND897068/1, Sandia National Laboratories, Albuquerque, NM. 
36. Davies, P.B., 1989, Variable-Density Ground-Water Flow and Paleohydrology in the Waste Isolation Pilot Plant (WIPP) Region, Southeastern New Mexico, United States Geological Survey Open-File Report 88-490, United States Geological Survey, Albuquerque, NM.

37. LaVenue, A.M., and RamaRao, B.S., 1992, A Modeling Approach to Address Spatial Variability within the Culebra Dolomite Transmissivity Field, SAND92-7306, Sandia National Laboratories, Albuquerque, NM.

38. Jones, T.L., Kelley, V.A., Pickens, J.F., Upton, D.T., Beauheim, R.L., and Davies, P.B., 1992, Integration of Interpretation Results of Tracer Tests Performed in the Culebra Dolomite at the Waste Isolation Pilot Plant Site, SAND92-1579, Sandia National Laboratories, Albuquerque, NM.

39. Beauheim, R.L., and Ruskauff, G.J., 1998, Analysis of Hydraulic Tests of the Culebra and Magenta Dolomites and Dewey Lake Redbeds at the Waste Isolation Pilot Plant Site, SAND98-0049, Sandia National Laboratories, Albuquerque, NM.

40. Schiel, K.A., 1988, "The Dewey Lake Formation: End Stage Deposit of a Peripheral Foreland Basin." Master's Thesis: University of Texas at El Paso, El Paso, TX.

41. Holt, R.M., and Powers, D.W., 1990, Geologic Mapping of the Air Intake Shaft at the Waste Isolation Pilot Plant, DOE/WIPP 90-051, United States Department of Energy, Carlsbad, NM.

42. New Mexico Bureau of Mines and Mineral Resources, 1995, Final Report Evaluation of Mineral Resources at the Waste Isolation Pilot Plant (WIPP) Site, Vols. 1 to 4, New Mexico Bureau of Mines and Mineral Resources, Socorro, NM, prepared for Westinghouse Electric Corporation Waste Isolation Division, Carlsbad, NM.

43. United States Environmental Protection Agency, 1996, "Title 40 Code of Federal Regulations Part 194, Criteria for the Certification and Re-Certification of the Waste Isolation Pilot Plant's Compliance with the 40 CFR Part 191 Disposal Regulations; Final Rule," Federal Register, vol. 61, no. 28, p. 5223-5245.

44. Helton et al. 1998. (this volume) 
45. Ramsey et al. 1998. (this volume)

46. Marietta et al. 1998. (this volume).

47. Corbet, T.F., and Knupp, P.M., 1996, The Role of Regional Groundwater Flow in the Hydrogeology of the Culebra Member of the Rustler Formation at the Waste Isolation Pilot Plant (WIPP), Southeastern New Mexico, SAND96-2133, Sandia National Laboratories, Albuquerque, NM.

48. Lambert, S.J., 1987, Feasibility Study: Applicability of Geochronologic Methods Involving Radiocarbon and Other Nuclides to the Groundwater Hydrology of the Rustler Formation, Southeastern New Mexico, SAND86-1054, Sandia National Laboratories, Albuquerque, NM.

49. Holt, R.M., 1997, Conceptual Model for Transport Processes in the Culebra Dolomite Member, Rustler Formation. SAND97-0194, Sandia National Laboratories, Albuquerque, NM. 